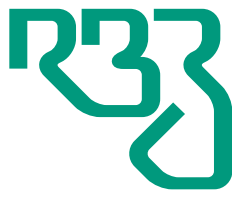

Revista Brasileira de Zootecnia

Brazilian Journal of Animal Science ISSN 1806-9290 www.rbz.org.br

\title{
Influence of forage production area, concentrate supply, and workforce on productive results in milk production systems
}

\author{
Guilherme Koerich $^{1^{*}}$ iD, Julio Cesar Damasceno² iD, Ferenc Istvan \\ Bánkuti² $^{2}$ iD, José Luiz Parré ${ }^{3}$ iD, Geraldo Tadeu dos Santos² (iD) \\ ${ }^{1}$ Universidade Estadual de Maringá, Programa de Pós-graduação em Zootecnia, Maringá, \\ PR, Brasil. \\ ${ }^{2}$ Universidade Estadual de Maringá, Departamento de Zootecnia, Maringá, PR, Brasil. \\ ${ }^{3}$ Universidade Estadual de Maringá, Departamento de Economia, Maringá, PR, Brasil.
}

\begin{abstract}
*Corresponding author: guilhermekoerich90@hotmail.com

Received: June 25, 2017

Accepted: May 27, 2018

How to cite: Koerich, G.; Damasceno, J. C.; Bánkuti, F. I.; Parré, J. L. and Santos, G. T. 2019. Influence of forage production area, concentrate supply, and workforce on productive results in milk production systems. Revista Brasileira de Zootecnia 48:e20170177.

https://doi.org/10.1590/rbz4820170177

Copyright: This is an open access article distributed under the terms of the

Creative Commons Attribution License

(http://creativecommons.org/licenses/by/4.0/), which permits unrestricted use, distribution, and reproduction in any medium, provided the original work is properly cited.
\end{abstract}

\begin{abstract}
This study aimed to investigate the influence of forage production area, concentrate supply, and farm labor on characterization of milk production systems (MPS) and their productive results. Milk volume data provided in 2014 by 110 dairy farms located in the eastern region of Santa Catarina State, Brazil, were obtained from a dairy industry. Forty-four farms with different production levels were selected, in which interviews were carried out aiming to characterize the management practices related to forage production area, concentrate supply, and farm labor. A principal component analysis (PCA) was performed. Then, regressions were made between the principal components (PC) and indicator variables of productive response (annual milk production, milk production per area, milk production per cow, milk production per worker on farm, and number of cows per hectare). Finally, we performed a hierarchical agglomerative cluster analysis based on the PCA, followed by comparison of the means between clusters. Three PC were generated: indicator of scale and intensification, indicator of age of the manager and his experience on dairy farming, and indicator of specialization and permanent family labor available. The three PC were influencing the production results, especially PC1. It was possible to form five clusters: cluster 1, characterized by the highest value in PC1, showed the highest production results, followed by the cluster 2, with intermediate values in PC1; clusters 3, 4, and 5, characterized by lower values in PC1 and distinguished by PC2 and PC3, had the lowest productive results. Aspects related to forage production area, concentrate supply, and workforce are important for MPS characterization and have significant influence on productive results.
\end{abstract}

Keywords: cluster, multivariate analysis, principal component analysis

\section{Introduction}

The milk agroindustrial system in Brazil is fundamental for the generation of income and labor, contributing to keep people on the farm (Campos and Piacenti, 2007). The state of Santa Catarina, despite occupying only the 20th place in territorial dimension, was the fifth largest milk producer in Brazil in 2015, with 3.06 billion liters (IBGE, 2016). This production comes from diversified and mainly low-scale milk production systems (MPS), posing challenges to the development of dairy activity as regards research, rural extension, and industry (Alves, 2000).

Each farm has its own characteristics, with distinct availability of resources and decision-making problems (Dixon et al., 2001; Köbrich et al., 2003). In reality, however, for the application of development 
strategies or public policies, it is necessary to study the production systems. For this purpose, the multivariate analysis, composed of principal component analysis and cluster analysis, has been used.

Due to their complexity, production systems can be studied from several points of view (Dixon et al., 2001). Among the several criteria used to classify production systems, especially grazing-based systems, it is possible to mention farm size, use of land for forage production, herd feeding, and available farm labor (Madry et al., 2013).

Considering the diverse possibilities of combinations of productive factors, it is assumed that MPS characteristics influence their own results (Chevereau, 2004; Damasceno et al., 2008). This relationship, however, is difficult to measure. The possibility of assigning the degree of influence of a variable, or a group of variables, on the productive results represents an important subsidy for decision-making, because it facilitates the allocation of resources to the most impacting factors in the sustainability of the MPS.

The objective of this study was to investigate the influence of forage production area, concentrate supply, and available farm labor on MPS characterization and its productive results.

\section{Material and Methods}

The study was carried out in São Bonifácio $\left(27^{\circ} 54^{\prime} 05^{\prime \prime}\right.$ S and $48^{\circ} 55^{\prime} 45^{\prime \prime}$ W) and São Martinho $\left(28^{\circ} 09^{\prime} 53^{\prime \prime} \mathrm{S}\right.$ and $\left.48^{\circ} 58^{\prime} 46^{\prime \prime} \mathrm{W}\right)$, located in the state of Santa Catarina, Brazil.

According to Köppen (1948), the climate of São Martinho is classified as Cfa, while in São Bonifácio $51 \%$ of the area is categorized as $\mathrm{Cfa}$ and $49 \%$ as $\mathrm{Cfb}$. The Cfa climate is described as subtropical, with no defined dry season, with average temperature in the hottest month above $22^{\circ} \mathrm{C}$ and average temperature in the coldest month below $18{ }^{\circ} \mathrm{C}$. The climate $\mathrm{Cfb}$ is temperate, with no defined dry season, with average temperature in the hottest month above $22^{\circ} \mathrm{C}$ and average temperature in the coldest month below $18^{\circ} \mathrm{C}$.

The relief of the region is typically undulating. According to the agroecological and socioeconomic zoning data of the state of Santa Catarina, land slope is the main limitation for land use in this region (Thomé et al., 1999).

Initially, individual milk volume data provided by all farmers in 2014 were obtained from a dairy industry in the region, as well as the identification and address of the farmers. Producers who did not provide milk to dairy industry in all months of the year were discarded from the sample, because it would not be possible to know their annual milk production. In total, 110 farmers provided milk to dairy industry in all months of the year.

The 110 dairy farms were arranged according to the annual milk production and subdivided into three groups: up to 20,000 L ( 37 farms), from 20,000 to 55,000 L (37 farms), and above 55,000 L (36 farms). Forty-four farms were proportionally selected amongst the different levels of annual milk production. Therefore, we tried to represent the different levels of production and to characterize faithfully the dairy farmers in the region.

The 44 farmers were contacted for interviews, which were carried out with the person in charge of the farm between January and March 2015 by means of semi-structured forms. The form contained questions divided into four modules to characterize the productive systems: workforce, forage production and land use, supply of concentrates for lactating cows, and demographics of the dairy herd.

The methodology proposed by Damasceno et al. (2005) was used to conduct the interviews. In this methodology, the interviewee speaks freely about the question posed, with minimum interference on the part of the interviewer to avoid the induction of certain answers. If necessary, the interviewer should punctually interfere with other questions until the answer is satisfactory according to the purpose of the study.

R. Bras. Zootec., 48:e20170177, 2019 
The information obtained was tabulated in a spreadsheet. To reduce the initial number of variables and to facilitate the understanding of the MPS, the principal components analysis (PCA) was performed on the original variables: number of people working on farm, manager age, number of years involved in dairying, total area, land available for milk production/total area, natural grassland/land available for milk production, land available for conserved forage production/land available for milk production, amount of chemical fertilizer, number of paddocks, and concentrate supply/cow/day (Table 1).

The criterion used to maintain or not a component was based on eigenvalues that should be higher than 1 to ensure clarity of analysis (Castel et al., 2010; Rivero et al., 2013). The Kaiser-Meyer-Olkin of sampling adequacy (KMO), whose result was 0.73 with significance lower than 0.05 in Bartlett's sphericity test, was used as a quality indicator of PCA. The value of the KMO test is adequate when equal to or greater than 0.5 , and Bartlett's sphericity test should be significant $(\mathrm{P}<0.05)$ (Williams et al., 2010; Beavers et al., 2013; Todde et al., 2016). To ensure the orthogonality of PC formed, the rotated component matrix was used.

Score values obtained by PC scores were used as independent variables in the multiple linear regression models (Çamdevýren et al., 2005) to analyze the effects of management variables on animal and production system responses, represented by variables annual milk production, milk production/ cow, milk production/total area, milk production/area intended for milk production, milk production/ number of people working on farm, and cows/area intended for milk production (Table 2).

Table 1 - Original variables, units, and abbreviations

\begin{tabular}{|c|c|c|}
\hline Variable & Unit & Abbreviation \\
\hline Number of people working on farm & Number & NumPeople \\
\hline Manager age & Years & ManaAge \\
\hline Number of years involved in dairying & Years & YearDairy \\
\hline Total area & ha & TotArea \\
\hline Land available for milk production ${ }^{1} /$ total area & $\%$ & LanMilkTotArea \\
\hline Natural grassland/land available for milk production & $\%$ & NatgLanMilk \\
\hline $\begin{array}{l}\text { Land available for conserved forage production }{ }^{2} / \text { land available for milk } \\
\text { production }\end{array}$ & $\%$ & LanConForMilk \\
\hline Amount of chemical fertilizer ${ }^{3}$ & kg/ha/year & AmounFert \\
\hline Number of paddocks & Number & Npad \\
\hline Concentrate supply/cow/day ${ }^{4}$ & $\mathrm{~kg} / \mathrm{cow} /$ day & ConcSupply \\
\hline
\end{tabular}

${ }^{1}$ Sum of plots composed of native or cultivated forage and conserved forage.

${ }^{2}$ Corn for ensiling, sugar cane, and fresh grass.

${ }^{3}$ Total amount of chemical fertilizers applied per hectare intended for milk production in 2014.

${ }^{4}$ Average amount of concentrate supplied to lactating cows on a daily basis.

Table 2 - Response variables, units, and abbreviations

\begin{tabular}{lcc}
\hline Variable & Unit & Abbreviation \\
\hline Annual milk production & & ProdYear \\
Milk production/cow $^{2}$ & $\mathrm{~L} \times 1000 /$ year & ProdCow \\
Milk production/total area & $\mathrm{L} /$ cow/day & ProdTotArea \\
Milk production/area intended for milk production & $\mathrm{L} \times 1000 /$ ha/year & ProdArMilk \\
Milk production/number of people working on farm & $\mathrm{L} \times 1000 /$ ha/year & ProdPeop \\
Cows/area intended for milk production & $\mathrm{L} \times 1000 /$ person/year & CowHaMilk \\
\hline
\end{tabular}

${ }^{1}$ Total volume of milk supplied to dairy industry in 2014.

${ }^{2}$ Milk production per lactating cow per day, considering the average daily production of the farm in 2014 and the average lactating cows in the same year. 
Multiple linear regression analysis of productive responses on PC scores was performed using stepwise variable selection procedures to identify the best predictors. Only score values of three first selected PC were included as independent variables, according to the following model:

$$
\mathrm{Y}=\mathrm{a}+\mathrm{b} 1 \mathrm{~s} 1+\mathrm{b} 2 \mathrm{~s} 2+\mathrm{b} 3 \mathrm{~s} 3+\mathrm{e},
$$

in which a is a constant term, bk is the regression coefficient of score values of kth PC, sk is the score values of kth PC, and e is the error term of the model. The $t$ test was used to test the regression coefficients.

The next step of the study was the hierarchical agglomerative cluster analysis, based on factorial scores derived from the PCA. The definition of the number of clusters was based on variances within each group (less than 25\%) and between groups (greater than 75\%) (Bodenmüller Filho et al., 2010). Hence, we sought to obtain the greatest possible heterogeneity amongst the groups and the highest possible homogeneity within each group, which is indicative of good clusters (Köbrich et al., 2003).

Finally, we compared the means (ANOVA) of the original variables and, later, of the response variables among the clusters formed. According to Madry et al. (2013), once the clusters were obtained, they can be described and compared by ANOVA or chi-square test. This is a method of contrasting production systems with hypotheses and validating the representativeness of cluster analysis (Köbrich et al., 2003).

Statistical analysis was performed using SPSS software, version 18.

\section{Results}

The three PC maintained explained $78.3 \%$ of the total variance (Table 3). The PCA originated the rotated component matrix, which allows the understanding of the PC generated from the original variables (Table 4).

Table 3 - Eigenvalues and percentage of total variance explained

\begin{tabular}{lccc}
\hline Principal component & Eigenvalue & Variance \% & Cumulative \% \\
\hline 1 & 4.982 & 49.821 & 49.821 \\
2 & 1.592 & 15.915 & 65.737 \\
3 & 1.253 & 12.527 & 78.263 \\
\hline
\end{tabular}

Table 4 - Rotated component matrix

\begin{tabular}{lccc}
\hline Variable $^{1}$ & PC1 & PC2 & PC3 \\
\hline NumPeople & & & 0.595 \\
ManaAge & & 0.937 & \\
YearDairy & & & \\
TotArea & 0.774 & & 0.906 \\
LanMilkTotArea & & & \\
NatgLanMilk & -0.805 & & \\
LanConForMilk & 0.800 & & \\
AmounFert & 0.890 & & \\
Npad & 0.689 & & \\
ConcSupply & 0.853 & \\
\hline
\end{tabular}

PC - principal component.

${ }^{1}$ NumPeople - number of people working on farm; ManaAge - manager age; YearDairy - number of years involved in dairying; TotArea - total area; LanMilkTotArea - land available for milk production/total area; NatgLanMilk - natural grassland/land available for milk production; LanConForMilk - land available for conserved forage production/land available for milk production; AmounFert - amount of chemical fertilizer/hectare intended for milk production; Npad - Number of paddocks; ConcSupply - concentrate supply/lactating cow/day. 
The PC1 explained $49.8 \%$ of the total variance and represents the variables total area (TotArea), natural grassland/land available for milk production (NatgLanMilk), land available for conserved forage production/land available for milk production (LanConForMilk), amount of chemical fertilizer (AmounFert), number of paddocks (Npad), and concentrate supply/cow/day (ConcSupply). This component is an indicator of scale and intensification, especially regarding forage production area use. Unlike the other variables, variable NatgLanMilk showed a negative value $(-0.805)$, since the lower percentage of native pasture area denotes greater utilization of cultivated pastures, usually associated with greater intensification.

The PC2 explained $15.9 \%$ of the total variance and represents the time that individuals are involved in dairying (YearDairy) and manager age (ManaAge). This component may be related to the experience of the manager and the evolution of farms over time or even to the aging of workforce.

The PC3 explained $12.5 \%$ of the total variance and is composed of variables number of people working on farm (NumPeople) and land available for milk production/total area (LanMilkTotArea). This component is an indicative of the degree of farm specialization and amount of permanent and family labor available.

The response variables ProdYear, ProdCow, ProdTotArea, and ProdArMilk showed a significant linear regression $(\mathrm{P}<0.05)$ with the three $\mathrm{PC}$. The coefficients of determination $\left(\mathrm{R}^{2}\right)$ of the regressions were 0.94 (ProdYear), 0.88 (ProdCow), 0.90 (ProdTotArea), 0.88 (ProdArMilk), 0.67 (ProdPeop), and 0.45 (CowHaMilk). The $\mathrm{R}^{2}$ values indicate the percentage of the variation of dependent variable (response variables) that can be explained by the multiple linear regression model composed by the PC.

The regression beta ( $\beta$ ) coefficients (Table 5) allowed to infer the degree of influence of each PC on the response variables. The $\beta_{1}$ values were positive for all variables and higher than $\beta_{2}$ and $\beta_{3}$. The PC1, therefore, was the most impacting component on the productive results. In applied terms, a unit of the synthetic variable PC1 represents an impact of 46,210 L in annual milk production and $3.56 \mathrm{~L}$ in daily productivity of cows, following the same logic for the other variables. The coefficients $\beta_{2}$ were negative for all variables, indicating that higher values in the synthetic variable PC2 are negatively associated to the productive performance. The coefficients $\beta_{3}$ were positive for variables ProdYear, ProdCow, ProdTotArea, and ProdArMilk. Variables ProdPeop and CowHaMilk were not significantly influenced by PC3.

The cluster analysis based on the PC determined the formation of five groups from the 44 farms. The farms (Figures 1 and 2) were projected in the two-dimensional spaces PC1×PC2 and PC1 $\times$ PC3, respectively.

Cluster 1 "focused on greater intensification" is composed of farms highlighted by PC1. They have a larger area (34.5 $\pm 5.1 \mathrm{ha})$, apply more chemical fertilizer annually $(118.0 \pm 10.3 \mathrm{~kg} / \mathrm{ha})$, divide pastures into more paddocks (54.8 \pm 7.7$)$, and supply higher average of concentrate for cows $(3.8 \pm 0.6 \mathrm{~kg} / \mathrm{day})$

Table 5 - Regression coefficients ( $\beta$ values) between response variables and principal components

\begin{tabular}{lccccc}
\hline Response variable $^{1}$ & $\begin{array}{c}\text { Constant } \\
\left(\beta_{0}\right)\end{array}$ & $\begin{array}{c}\text { PC1 } \\
\left(\beta_{1}\right)\end{array}$ & $\begin{array}{c}\text { PC2 } \\
\left(\beta_{2}\right)\end{array}$ & $\begin{array}{c}\text { PC3 } \\
\left(\beta_{3}\right)\end{array}$ & SE \\
\hline ProdYear (L×1000/year) & $56.16^{*}$ & $46.21^{*}$ & $-7.96^{*}$ & $12.58^{*}$ & 2.02 \\
ProdCow (L/cow/day) & $11.44^{*}$ & $3.56^{*}$ & $-0.69^{*}$ & $0.76^{*}$ & 0.22 \\
ProdTotArea (L×1000/ha/year) & $2.10^{*}$ & $1.18^{*}$ & $-0.40^{*}$ & $0.64^{*}$ & 0.07 \\
ProdArMilk (L×1000/ha/year) & $4.30^{*}$ & $2.28^{*}$ & $-0.80^{*}$ & $0.34^{*}$ & 0.14 \\
ProdPeop (L×1000/person/year) & $30.04^{*}$ & $22.05^{*}$ & $-5.70^{*}$ & -2.10 & 2.49 \\
CowHaMilk (n/ha) & $1.34^{*}$ & $0.22^{*}$ & $-0.16^{*}$ & 0.03 & 0.05 \\
\hline
\end{tabular}

PC - principal component; SE - standard error.

${ }_{1}^{1}$ ProdYear - annual milk production; ProdCow - milk production/lactating cow/day; ProdTotArea - milk production/total area; ProdArMilk - milk production/area intended for milk production; ProdPeop - milk production/number of people working on farm; CowHaMilk - cows/area intended for milk production.

* Significant $(\mathrm{P}<0.05)$. 


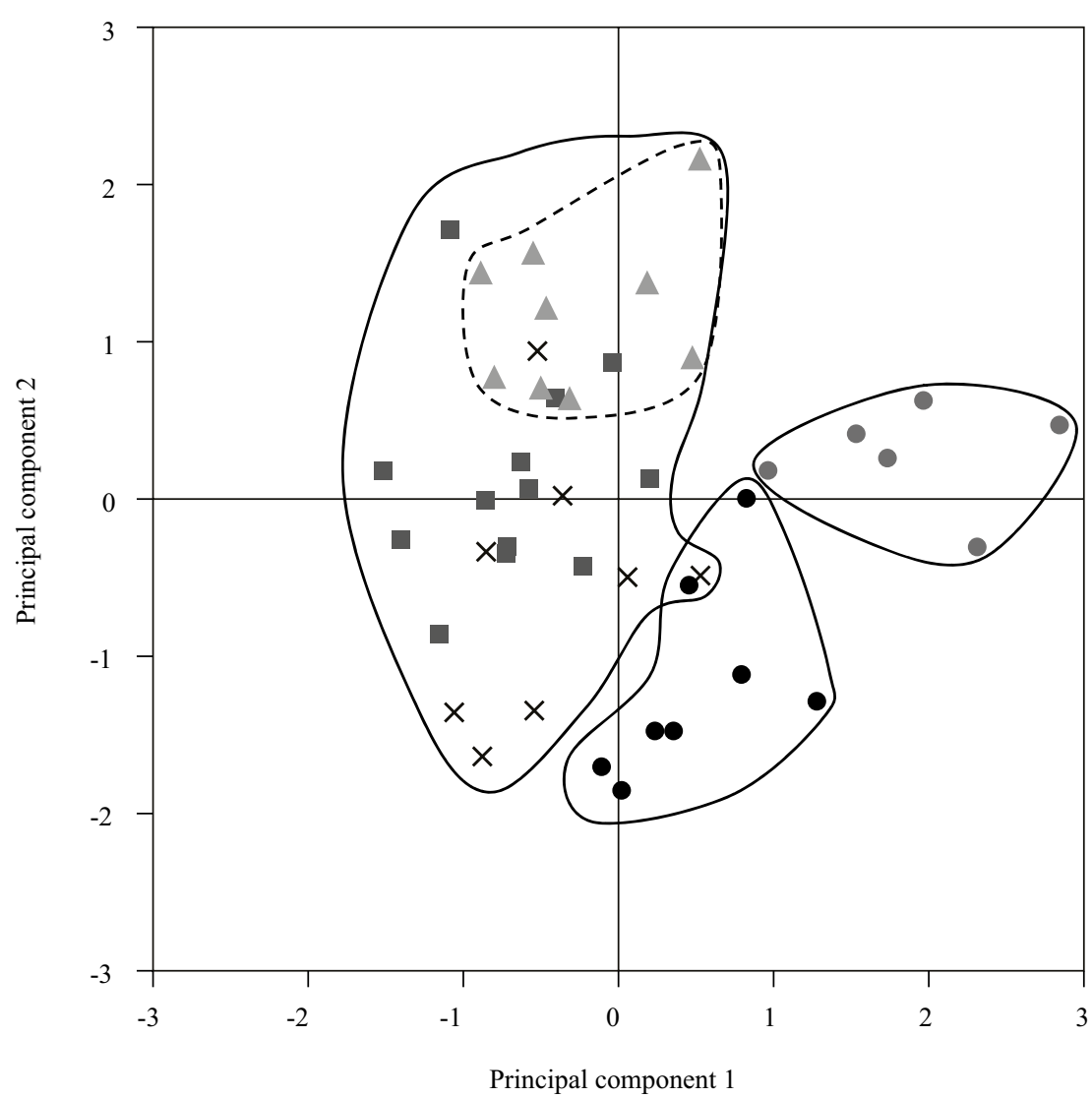

Cluster 1

- Cluster 2

Cluster 3

$\triangle$ Cluster 4

$\mathbf{X}$ Cluster 5

Figure 1 - Distribution of the farms from the intersection of principal components 1 and 2.

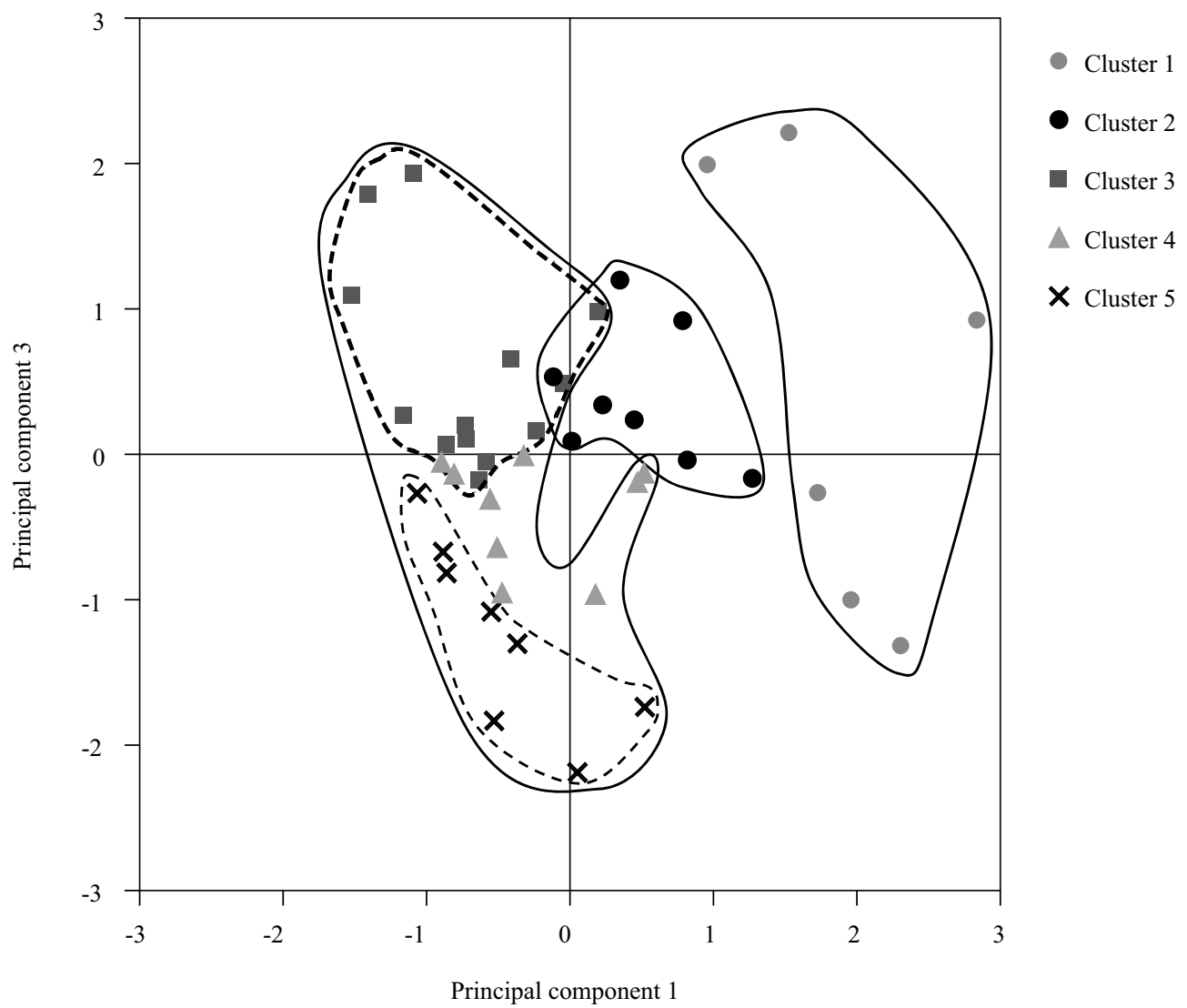

Figure 2 - Distribution of the farms from the intersection of principal components 1 and 3. 
(Table 6). In addition, $19 \%$ of the land destined to milk production is covered with native pastures and $20 \%$ of the area is destined to the cultivation of conserved forages.

Cluster 2, "intermediate intensification and young managers", in general, is located in an intermediate position between cluster 1 and the other clusters in relation to PC1. Farms have smaller area compared with cluster 1 and similar to other clusters $(25.0 \pm 3.3 \mathrm{ha})$. Fertilization level $(86.8 \pm 8.7 \mathrm{~kg} / \mathrm{ha})$ and number of paddocks (34.3 \pm 2.5$)$ are lower than cluster 1 and higher than clusters 3,4 , and $5(\mathrm{P}<0.05)$. Native pasture $(26.2 \pm 4.9 \%)$ and forage conservation areas $(16.4 \pm 2.0 \%)$ are similar to cluster 1 and higher than clusters 3,4 , and $5(\mathrm{P}<0.05)$. This cluster is also notable for having younger managers ( $34.9 \pm 2.5$ years) and people with less time spent on milk activity ( $9.8 \pm 1.8$ years).

Clusters 3, 4, and 5 are subdivisions of a large group of lower intensification in PC1. The farms that compose these clusters have a higher percentage of the area covered with native forage, use less intensively conserved forage cultures, apply lesser amounts of fertilizers, have fewer paddocks to divide pasture, and supply less concentrate for cows. These clusters, therefore, are distinguished from each other as a function of PC2 and PC3.

Cluster 3, "less intensification and greater specialization", stands out for PC3, with an average of two people working on farm and the highest percentage of total area actually used in milk production

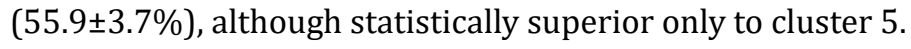

Cluster 4, "less intensification and older managers", have the oldest managers (63.2 \pm 3.7 years) and people with the longest time in milk activity (27.0 \pm 3.7 years), standing out for PC2.

Cluster 5, "less intensification and low workforce availability", showed the lowest number of people working on farm $(1.4 \pm 0.2)$ and the smallest proportion of the area intended for milk production $(34.9 \pm 3.6 \%)$. This cluster has relatively young managers ( $44.9 \pm 3.9$ years) and people with less time spent on milk activity (11.5 \pm 2.1 years) when compared with clusters 3 and 4 , although it is statistically different only from cluster 4.

Regarding response variables (Table 7), the annual milk production was higher in cluster 1 $(153,300 \pm 18,900 \mathrm{~L})$, followed by cluster $2(84,900 \pm 7,400 \mathrm{~L})$, and later by other clusters that did not

Table 6 - Means and standard errors for original variables in the clusters

\begin{tabular}{|c|c|c|c|c|c|}
\hline Variable $^{1}$ & $\begin{array}{c}\text { Cluster } 1 \\
(\mathrm{n}=6)\end{array}$ & $\begin{array}{c}\text { Cluster } 2 \\
(\mathrm{n}=8)\end{array}$ & $\begin{array}{c}\text { Cluster } 3 \\
(\mathrm{n}=13)\end{array}$ & $\begin{array}{c}\text { Cluster } 4 \\
(\mathrm{n}=9)\end{array}$ & $\begin{array}{c}\text { Cluster } 5 \\
(\mathrm{n}=8)\end{array}$ \\
\hline \multicolumn{6}{|c|}{ Principal component 1} \\
\hline TotArea (ha) & $34.5 \pm 5.1 \mathrm{a}$ & $25.0 \pm 3.3 \mathrm{~b}$ & $20.1 \pm 2.8 \mathrm{~b}$ & $23.2 \pm 3.1 \mathrm{~b}$ & $26.9 \pm 5.5 \mathrm{ab}$ \\
\hline NatgLanMilk (\%) & $19.2 \pm 4.6 \mathrm{~b}$ & $26.2 \pm 4.9 \mathrm{~b}$ & $74.3 \pm 3.8 \mathrm{a}$ & $75.1 \pm 4.56 \mathrm{a}$ & $70.1 \pm 5.4 a$ \\
\hline LanConForMilk (\%) & $20.7 \pm 2.6 \mathrm{a}$ & $16.4 \pm 2.0 \mathrm{a}$ & $2.4 \pm 1.0 \mathrm{~b}$ & $0.6 \pm 1.0 \mathrm{~b}$ & $1.2 \pm 0.6 \mathrm{~b}$ \\
\hline AmounFert (kg/ha/year) & $118.0 \pm 10.3 a$ & $86.8 \pm 8.7 \mathrm{~b}$ & $9.4 \pm 4.6 \mathrm{c}$ & $11.4 \pm 7.6 \mathrm{c}$ & $6.4 \pm 12.3 \mathrm{c}$ \\
\hline Npad (n) & $54.8 \pm 7.7 \mathrm{a}$ & $34.3 \pm 2.5 \mathrm{~b}$ & $14.3 \pm 2.5 \mathrm{c}$ & $9.4 \pm 2.9 \mathrm{c}$ & $13.1 \pm 3.2 \mathrm{c}$ \\
\hline ConcSupply (kg/cow/day) & $3.8 \pm 0.6 \mathrm{a}$ & $2.5 \pm 0.4 \mathrm{~b}$ & $1.6 \pm 0.2 \mathrm{bc}$ & $1.7 \pm 0.3 \mathrm{bc}$ & $1.5 \pm 0.4 \mathrm{c}$ \\
\hline \multicolumn{6}{|c|}{ Principal component 2} \\
\hline ManaAge (year) & $44.0 \pm 4.8 \mathrm{bc}$ & $34.9 \pm 2.5 \mathrm{c}$ & $53.0 \pm 2.0 \mathrm{ab}$ & $63.2 \pm 3.7 \mathrm{a}$ & $44.9 \pm 3.9 \mathrm{bc}$ \\
\hline YearDairy (year) & $19.3 \pm 2.2 \mathrm{ab}$ & $9.8 \pm 1.8 \mathrm{c}$ & $18.8 \pm 2.3 \mathrm{abc}$ & $27.0 \pm 3.7 \mathrm{a}$ & $11.5 \pm 2.1 \mathrm{bc}$ \\
\hline \multicolumn{6}{|c|}{ Principal component 3} \\
\hline NumPeople (n) & $2.3 \pm 0.3 \mathrm{a}$ & $2.0 \pm 0.3 \mathrm{ab}$ & $2.0 \pm 0.1 \mathrm{ab}$ & $1.8 \pm 0.1 \mathrm{ab}$ & $1.4 \pm 0.2 \mathrm{~b}$ \\
\hline LanMilkTotArea (\%) & $54.3 \pm 6.1 \mathrm{a}$ & $51.8 \pm 4.4 \mathrm{a}$ & $55.9 \pm 3.7 \mathrm{a}$ & $41.4 \pm 4.9 \mathrm{ab}$ & $34.9 \pm 3.6 \mathrm{~b}$ \\
\hline
\end{tabular}

${ }^{1}$ TotArea - total area; NatgLanMilk - natural grassland/land available for milk production; LanConForMilk - land available for conserved forage production/land available for milk production; AmounFert - amount of chemical fertilizer/hectare intended for milk production; Npad - number of paddocks; ConcSupply - concentrate supply/lactating cow/day; ManaAge - manager age; YearDairy - number of years involved in dairying; NumPeople - number of people working on farm; LanMilkTotArea - land available for milk production/total area.

Means followed by different letters in the same row differ by Tukey's test $(\mathrm{P}<0.05)$. 
Table 7 - Means and standard errors for response variables in the clusters

\begin{tabular}{lccccc}
\hline Variable $^{1}$ & $\begin{array}{c}\text { Cluster 1 } \\
(\mathrm{n}=6)\end{array}$ & $\begin{array}{c}\text { Cluster 2 } \\
(\mathrm{n}=8)\end{array}$ & $\begin{array}{c}\text { Cluster 3 } \\
(\mathrm{n}=13)\end{array}$ & $\begin{array}{c}\text { Cluster 4 } \\
(\mathrm{n}=9)\end{array}$ & $\begin{array}{c}\text { Cluster } 5 \\
(\mathrm{n}=8)\end{array}$ \\
\hline ProdYear (L×1000/year) & $153.3 \pm 18.9 \mathrm{a}$ & $84.9 \pm 7.4 \mathrm{~b}$ & $31.0 \pm 5.0 \mathrm{c}$ & $24.7 \pm 18.6 \mathrm{c}$ & $30.8 \pm 6.8 \mathrm{c}$ \\
ProdCow (L/cow/day) & $18.2 \pm 1.4 \mathrm{a}$ & $13.9 \pm 1.1 \mathrm{~b}$ & $9.8 \pm 0.6 \mathrm{c}$ & $9.0 \pm 2.4 \mathrm{c}$ & $9.4 \pm 0.9 \mathrm{c}$ \\
ProdTotArea (L×1000/ha/year) & $4.5 \pm 0.5 \mathrm{a}$ & $3.4 \pm 0.5 \mathrm{a}$ & $1.5 \pm 0.2 \mathrm{~b}$ & $1.0 \pm 0.6 \mathrm{~b}$ & $1.2 \pm 0.2 \mathrm{~b}$ \\
ProdArMilk (L×1000/ha/year) & $8.4 \pm 0.7 \mathrm{a}$ & $6.6 \pm 0.7 \mathrm{a}$ & $2.9 \pm 0.4 \mathrm{~b}$ & $2.5 \pm 1.3 \mathrm{~b}$ & $3.3 \pm 0.6 \mathrm{~b}$ \\
ProdPeop (L×1000/person/year) & $75.8 \pm 18.2 \mathrm{a}$ & $42.4 \pm 7.4 \mathrm{~b}$ & $15.2 \pm 1.9 \mathrm{c}$ & $14.2 \pm 9.0 \mathrm{c}$ & $25.4 \pm 6.2 \mathrm{bc}$ \\
CowHaMilk (n/ha) & $1.7 \pm 0.1 \mathrm{a}$ & $1.7 \pm 0.2$ & $1.2 \pm 0.1 \mathrm{~b}$ & $1.1 \pm 0.2 \mathrm{~b}$ & $1.3 \pm 0.2 \mathrm{~b}$ \\
\hline
\end{tabular}

${ }^{1}$ ProdYear - annual milk production; ProdCow - milk production/lactating cow/day; ProdTotArea - milk production/total area; ProdArMilk - milk production/area intended for milk production; ProdPeop - milk production/number of people working on farm; CowHaMilk - cows/area intended for milk production.

Means followed by different letters in the same row differ by Tukey's test $(\mathrm{P}<0.05)$.

differ among them. The same trend was observed in daily productivity per cow, in which cluster 1 obtained the highest average $(18.2 \pm 1.4 \mathrm{~L})$, followed by cluster $2(13.9 \pm 1.1 \mathrm{~L})$ and clusters 3,4 , and 5 , whose means were lower than $10 \mathrm{~L}$.

Milk yields per total area and per area intended for milk production were higher in clusters 1 and 2 than in clusters 3,4 , and $5(\mathrm{P}<0.05)$. The annual milk yield per person working on farm was higher in cluster $1(75,800 \pm 18,200 \mathrm{~L})$ followed by clusters 2 and 5 and clusters 3 and 4 , which did not differ from cluster 5 . Clusters 1, 2, and 5 had higher number of cows per hectare intended for milk production, on average, followed by clusters 3 and 4, which did not differ from cluster 5 . The sloping relief in part of the land available for milk production explains the relatively low stocking rates in all the clusters of the region.

\section{Discussion}

The accumulated variance in the three PC was 78.3\% (Table 3), which is considered adequate for this type of study (Sraïri and Kiade, 2005; Castel et al., 2010). The fact that a large part of the total variance can be explained by PC indicates that it is feasible to use them in substitution for original variables, keeping much of the information (Barroso and Artes, 2003).

Considering that PC1 carries most of the variance, the variables that compose it contribute most to the discrimination of farms in different clusters (Castel et al., 2010). Nonetheless, it should be noted that no PC kept in PCA analysis (eigenvalue $>1$ ) should be neglected. Due to the great diversity of MPS, especially those grazing-based (Madry et al., 2013), the other PC are important in discriminating some clusters.

The outstanding influence of PC1 on variables of productive response (Table 5) is explained by the original variables that compose it. The availability of land (TotArea), usually limited in family farming in southern Brazil, is an important resource that allows scale gains in grazing-based milk production (Ferrari et al., 2005). The use of more productive forage species than the native pastures of the region, as well as the allocation of part of the area for the production of conserved forage, are important strategies to intensify the production. According to Rangrab et al. (2012), in Santa Catarina, the use of conserved forage is important due to the seasonality in forage production between growth periods of tropical or subtropical forages and temperate forages. Similarly, fertilization is one of the factors that most influence pasture productivity (Hanisch et al., 2012), and concentrate supply for grazing-based dairy cows in MPS has a significant impact on milk production (Bargo et al., 2003). The division of pasture in paddocks, characterized by short grazing periods followed by a rest period, has been increasing in Santa Catarina to allow better forage recovery after grazing to use it at the timeliest moment (Pedroso et al., 2012). 
Regressions between the PC and productive results of the MPS allow us to ponder whether a PC represents a strength or a limitation. Regarding PC2, the negative values of $\beta_{2}$ coefficients suggest that older managers with many years in dairying are associated with lower values of annual milk production, productivity per cow, production/total area, production per area intended for milk production, individual production, and stocking rate.

Older farmers tend to have less motivation for investments, improvements, and growth in activity. In the study conducted by Paixão et al. (2015), dairy farmers receiving retirement were 9.3 times more likely to have a total bacterial count in milk above $43,000 \mathrm{cfu} \mathrm{mL}^{-1}$. Due to the process of rural flight and aging in the Brazilian countryside in the last decades (Maia and Bauinain, 2015), it is common to exist no family farm succession nowadays, limiting the prospects of farm evolution in the long-term.

The $\beta_{3}$ coefficients determine the positive influence of PC3 for variables ProdYear, ProdCow, ProdTotArea, and ProdArMilk. Considering that one of the main bottlenecks of family-based milk production is labor-related problems (Santos Filho et al., 2012), the greater numerical availability of labor force is a positive aspect for milk production. Likewise, the greater allocation of area intended for milk production represents better possibilities to obtain superior productive results.

Possible approaches to the development of MPS in the region should prioritize investment in pasture establishment, fertilization, division of paddocks, production of conserved forage for periods of low pasture productivity, and adequate concentrate supply (PC1). This recommendation should not be applied in a generic way but should rather consider the unique characteristics of each production system (Whitfield et al., 2015), such as those associated to the age of the manager, time in activity, numerical availability of workers, and use of area intended for milk production (PC2 and PC3). According to Hostiou and Dedieu (2009), the intensification of the forage system in MPS demands a great amount of labor and, when there is a limitation on family labor force and there is no possibility of hiring employees, it is necessary to define priority tasks. Therefore, the pace and level of intensification of each farm should respect its potentialities and limitations.

Although having smaller effect on the productive results, PC2 and PC3 are relevant in the characterization of some MPS. These components stand out when the evolution of the profile of the typical Brazilian rural family in the last decades is considered, which has become increasingly smaller and older, especially in the South (Maia and Bauinain, 2015). Better working conditions may indicate more favorable development prospects, or even greater stability of long-term production systems.

The productive results of the clusters (Table 7) corroborate the idea that the intensification of forage production area use and concentrate supply strongly affects the productive results. Cluster 1, which showed the highest productive results, is characterized by PC1 intensification. Similarly, cluster 2, with intermediate intensification in PC1, also demonstrated intermediate results. On the other hand, clusters 3,4 , and 5 , whose productive results were lower in all variables, are characterized by lower intensification in PC1. The PC 2 and 3 distinguish these clusters but have smaller effect on the productive results, although they have been statistically associated with the response variables.

Although the reality of each farm is different, cluster 1 is important, because it serves as reference. Consequently, the other clusters in the region can evolve in search of better productive results. Since they are located in the same region, despite the individual differences that must be considered, clusters are subject to similarities in institutional and organizational environments, natural features such as relief, temperature, and rainfall, as well as cultural patterns.

Cluster 2 can be considered promising, since it presents intermediate levels of intensification in forage production area use and productive results in relation to the pattern of the studied region. In addition, PC2 has a positive factor because its managers are young and have less time spent on the activity. It is possible to speculate that, in the future, some farms belonging to cluster 2 can migrate to cluster 1.

Clusters 3,4 , and 5 , which together represent $68.2 \%$ of the studied farms, have the low intensification in forage production area use and the lower productive results as great limitations. In cluster 4 , the aging of managers is a worrying factor. In cluster 5, although managers are younger, fewer people 
working on farm can limit the strength and flexibility of work, posing challenges to the adoption of new technologies. The low proportion of the area intended for milk production (34.9\%) in this cluster may reflect the limited labor force. On the other hand, cluster 3 has the advantage of allocating a higher percentage of area to milk production with lower labor limitations, both in age and in number, when compared with clusters 4 and 5 .

The understanding of the different types of MPS in a region, including its main potentialities and limitations, is preponderant for the definition of development strategies adjusted to local realities. Information of this nature is valuable to farmers, industry and technical assistance agencies, and rural extension, since it helps in decision-making and allow the allocation of resources to be as effective as possible, both within the farm and at the regional level.

\section{Conclusions}

The first principal component, mainly related to the forage production area intensification and concentrate supply, is fundamental to characterize milk production systems and presents high positive impact on productive results. Characteristics associated to labor force, contained on principal components 2 and 3 , are relevant for the discrimination of some milk production systems and have influence on productive results, but in a small degree.

The application of regressions is relevant to determine more precisely the relationship between the characterization of milk production systems, represented by the principal components, and their productive results.

\section{References}

Alves, E. R. A. 2000. Fatores que interferem na transferência e adoção de tecnologia na atividade leiteira. p.175-191. In: Anais dos Simpósio Sustentabilidade da Pecuária de Leite no Brasil. Embrapa Gado de Leite, Juiz de Fora.

Bargo, F.; Muller, L. D.; Kolver, E. S. and Delahoy, J. E. 2003. Invited Review: Production and digestion of supplemented dairy cows on pasture. Journal of Dairy Science 86:1-42. https://doi.org/10.3168/jds.S0022-0302(03)73581-4

Barroso, L. P. and Artes, R. 2003. Análise multivariada. p.152. In: Anais do 10ํㅗㅇo Sísio de Estatística Aplicada à Experimentação Agronômica. Universidade Federal de Lavras, Lavras.

Beavers, A. S.; Lounsbury, J. W.; Richards, J. K.; Huck, S. W.; Skolits, G. J. and Esquivel, S. L. 2013. Practical considerations for using exploratory factor analysis in educational research. Practical Assessment, Research \& Evaluation 18:1-13.

Bodenmüller Filho, A.; Damasceno, J. C.; Previdelli, I. T. S.; Santana, R. G.; Ramos, C. E. C. O. and Santos, G. T. 2010. Tipologia de sistemas de produção baseada nas características do leite. Revista Brasileira de Zootecnia 39:1832-1839.

Çamdevýren, H.; Demýr, N.; Kanik, A. and Keskýn, S. 2005. Use of principal component scores in multiple linear regression models for prediction of Chlorophyll-a in reservoirs. Ecological Modelling 181:581-589. https://doi.org/10.1016/j.ecolmodel.2004.06.043

Campos, C. K. and Piacenti, C. A. 2007. Agronegócio do leite: cenário atual e perspectivas. p.1-19. In: Anais do 45o Congresso da Sociedade Brasileira de Economia, Administração e Sociologia Rural. Sociedade Brasileira de Economia, Administração e Sociologia Rural, Londrina.

Castel, J. M.; Madry, W.; Gozdowski, D.; Roszkowska-Madra, B.; Dàbrowski, M.; Lupa, W. and Mena, Y. 2010. Family dairy farms in the Podlasie province, Poland: farm typology according to farming system. Spanish Journal of Agricultural Research 8:946-961. https://doi.org/10.5424/sjar/2010084-1390

Chevereau, C. 2004. Pilotage stratégique des troupeaux laitiers. Dissertação (M.Sc.). École Supérieure d’Agriculture, Toulouse.

Damasceno, J. C.; Macombe, C.; Moinet, M. H.; Pailleux, J. Y.; Cournut, S. and Dedieu, B. 2005. Vers des projets d'élevage raisonnés en commun? Analyse de 12 démarches de commercialisation associant de petits groupes d'éleveurs laiters. p.212-212. In: Annales 12 ème Rencontres Recherches Ruminants. Institut de l'Elevage, Paris.

Damasceno, J. C.; Bodenmüller Filho, A.; Ramos, C. E. C. O.; Santos, J. C. and Santos, G. T. 2008. 0 papel do homem na gestão e controle de qualidade da produção de leite. p.276-287. In: Bovinocultura de leite: inovação tecnológica e sustentabilidade. Santos, G. T. et al., ed. Eduem, Maringá.

Dixon, J.; Gulliver, A. and Gibbon, D. 2001. Farming systems and poverty: Improving farmers' livelihoods in a changing world. FAO, Rome.

R. Bras. Zootec., 48:e20170177, 2019 
Ferrari, D. L.; Mello, M. A.; Testa, V. M. and Silvestro, M. L. 2005. Agricultores familiares, exclusão e desafios para inserção econômica na produção de leite em Santa Catarina. Revista Informações Econômicas 35:22-36.

Hanisch, A. L.; Fonseca, J. A.; Scherer, E.; Córdova, U. A. and Reck, J. P. D. 2012. Adubação de pastagens. p.205-236. In: Produção de leite à base de pasto em Santa Catarina. Córdova, U. A., ed. Epagri, Florianópolis.

Hostiou, N. and Dedieu, B. 2009. Diversity of forage system work and adoption of intensive techniques in dairy cattle farms of Amazonia. Agronomy for Sustainable Development 29:535-544.

IBGE - Instituto Brasileiro de Geografia e Estatística. 2016. Produção da pecuária municipal 2015. Rio de Janeiro.

Köbrich, C.; Rehman, T. and Khan, M. 2003. Typification of farming systems for constructing representative farm models: two illustrations of the application of multi-variate analyses in Chile and Pakistan. Agricultural Systems 76:141-157. https://doi.org/10.1016/S0308-521X(02)00013-6

Köppen, W. 1948. Climatologia: con un estudio de los climas de la tierra. Fondo de Cultura Econômica. Pánuco, México.

Madry, W.; Mena, Y.; Roszkowska-Madra, B.; Gozdowski, D.; Hryniewski, R. and Castel, J. M. 2013. An overview of farming system typology methodologies and its use in the study of pasture-based farming system: a review. Spanish Journal of Agricultural Research 11:316-326. https://doi.org/10.5424/sjar/2013112-3295

Maia, G. A. and Bauinain, A. M. 2015. O novo mapa da população rural brasileira. Confins 25. Available at:<https://confins. revues.org/10548>. Accessed on: Mar. 25, 2017.

Paixão, M. G.; Souza, G. N.; Lopes, M. A.; Costa, G. M.; Abreu, L. R. and Pinto, S. M. 2015. Socioeconomic and technical assistance factors related to total bacteria count and somatic cell count of milk bulk tanks in southern Minas Gerais State, Brazil. Ciência Rural 45:1241-1248. https://doi.org/10.1590/0103-8478cr20140895

Pedroso, M. S.; Córdova, U. A.; Dalgallo, D.; Kolling, A.; Teixeira, E. B. 2012. Manejo de pastagens perenes. p.237-273. In: Produção de leite à base de pasto em Santa Catarina. Córdova, U. A., ed. Epagri, Florianópolis.

Rangrab, L. H.; Rech, A. F.; Trevisan, I. and Massotti, Z. 2012. Conservação de forragem. p.275-334. In: Produção de leite à base de pasto em Santa Catarina. Córdova, U. A., ed. Epagri, Florianópolis.

Rivero, J. A.; Mantecón, A. R.; Álvarez, C. J. and Lavín, P. 2013. A typological characterization of dairy Assaf breed sheep farms at NW of Spain based on structural factor. Agricultural Systems 120:27-37. https://doi.org/10.1016/j.agsy.2013.05.004

Santos Filho, J. C.; Hostiou, N.; Damasceno, J. C.; Dedieu, B. and Pailleux, J. Y. 2012. Margem de manobra em tempo e flexibilidade na organização do trabalho em fazendas leiteiras do Brasil e da França. p.131-150. In: V Sul Leite: Simpósio sobre Sustentabilidade da Pecuária Leiteira da Região Sul do Brasil. Santos, G. T. et al., ed. Nova Sthampa, Maringá.

Sraïri, M. T. and Kiade, N. 2005. Typology of dairy cattle farming systems in the Gharb irrigated perimeter, Morroco. Livestock Research for Rural Development 17(1).

Thomé, V. M. R.; Zampieri, S.; Braga, H. J.; Pandolfo, C.; Silva Júnior, V. P.; Bacic, I.; Laus Neto, J.; Soldateli, D.; Gebler, E. F.; Dalle Ore, J. A.; Echeverria, L. C. R.; Mattos, J. F. and Suski, P. P. 1999. Zoneamento Agroecológico e Socioeconômico do Estado de Santa Catarina. Epagri, Florianópolis.

Todde, G.; Murgia, L.; Caria, M. and Pazzona, A. 2016. A multivariate statistical analysis approach to characterize mechanization, structural and energy profile in Italian dairy farms. Energy Reports 2:129-134. https://doi.org/10.1016/j.egyr.2016.05.006

Williams, B.; Brown, T. and Onsman, A. 2010. Exploratory factor analysis: A five-step guide for novices. Australasian Journal of Paramedicine 8:1-13.

Whitfield, S.; Dixon, J. L.; Mulenga, B. P. and Ngoma, H. 2015. Conceptualising farming systems for agricultural development research: Cases from Eastern and Southern Africa. Agricultural Systems 133:54-62. https://doi.org/10.1016/j.agsy.2014.09.005 